\title{
Pengaruh Perubahan Merek Dan Kepuasaan Konsumen Terhadap Loyalitas Pelanggan Pada Fifgroup
}

\author{
Elpa Hermawan \\ Universitas Bina Sarana Informatika \\ e-mail: elpa.ehn@bsi.ac.id
}

\begin{abstract}
The aims of research is to find out the effect of brand changes and consumer satisfaction on consumer loyality at FIFGROUP. The research method used descriptive quantitative survey and data collection technique used area sampling techniques with the number of respondents were 150 people. . The technique of data analysis is multiple linear regression equation. The results of research showed that customers understand the changes of brand and logo of the company, but the results of the calculations show that there is no influence of the change of brand and customer satisfaction to customer loyalty. In conducting this recearch, the researchers was faced by some constraints, especially constraints to obtain data on the number of customer's detail, as well as data concerning the company's consideration in making the change of brand and logo, so further research is effective to do.
\end{abstract}

Keywords : Branding, Customer Satisfaction, Customer Loyalty

\section{PENDAHULUAN}

Merek (brand) memiliki kekuatan penting yang menjadi pembeda diantara produk sejenis. Untuk itu, perusahaan harus melakukan kajian terhadap merek yang dimiliki apakah perlu dilakukan perubahan atau tetap akan bertahan. The American Marketing Association (AMA) mendefinisikan brand sebagai "nama, istilah, simbol, desain, atau kombinasi diantaranya yang mengidentifikasi antara penjual barang dan jasa satu dengan yang lainnya dan untuk membedakan mereka dari kompetitornya."(Keller, Aperia, \& Georgson, 2008). Menurut America Marketing Association (Kotler \& Keller, 2007), merek adalah nama, istilah, tanda, simbol, atau rancangan, atau kombinasi dari semuanya, yang dimaksudkan untuk mengidentifikasi barang atau jasa penjual atau kelompok penjual dan untuk mendiferensiasikannya dari barang atau jasa pesaing. Menurut Aaker dalam Ratri (2007), merek adalah cara membedakan sebuah nama dan atau simbol (logo, trademark, atau kemasan) yang dimaksudkan untuk mengidentifikasikan barang atau jasa dari satu produsen atau satu kelompok produsen dan untuk membedakan barang atau jasa itu dari produsen pesaing

Merek lebih dari sekedar simbol karena merek terbaik akan memberikan jaminan mutu. Oleh karena itu perbaikan terhadap merek harus dilakukan guna meningkatkan citra merek dimata pelanggan. Perusahaan juga dapat melakukan perubahan merek demi mempertahankan loyalitas pelanggan. Menurut Schultz (2004) bahwa branding merupakan brand building, dimana brand building dalam bahasa Indonesia diterjemahkan sebagai sebuah proses pembangunan sebuah merek. Muzzellec dan Lambkin (2006), pengertiaan yang tepat dari rebranding, yaitu menciptakan suatu nama yang baru, istilah, simbol, desain atau suatu kombinasi kesemuanya untuk satu brand yang tidak dipungkiri dengan tujuan dari mengembangkan diferensiasi (baru) posisi di dalam pikiran stakeholders dan pesaing. Dari pemahaman tersebut diketahui bahwa proses rebranding memiliki beberapa tahapan. Seperti yang dikatakan Kertajaya (2004) menyatakan bahwa untuk melakukan rebranding perlu diidentifikasi tiga tahapan utama, yaitu (1) faktor latar belakang, (2) proses, dan (3) hasil.

Re-branding dapat beragam bentuknya. Dapat namanya, desain atau simbolnya yang akan berubah. Dapat pula namanya tetap, tetapi desain dan simbolnya berubah. Begitu pula cara pembangunan mereknya akan berubah, tentunya akan ada strategi baru dengan adanya perubahan brand tersebut. Menurut Juntunen, Saraniemi, \& Jussila (2009), Rebranding perusahaan adalah proses sistematis direncanakan dan dilaksanakan perencanaan, menciptakan dan mempertahankan citra baik baru dan akibatnya reputasi yang menguntungkan bagi perusahaan secara keseluruhan dengan mengirimkan sinyal kesemua stakeholder dan dengan mengelola perilaku, komunikasi, dan simbolisme dalam rangka proact atau bereaksi terhadap perubahan.

PT Federal International Finance (FIF) perusahaan pembiayaan yang fokus pada pembiayaan sepeda motor Honda serta elektronik dan perabot rumah tangga. Di hari jadi yang ke-24, FIF secara resmi meluncurkan nama dan logo baru kepada masyarakat luas. PT Federal International Finance (FIF) saat itu resmi menjadi FIFGROUP.

Peluncuran nama dan logo baru ini merupakan wujud strategi transformasi bisnis PT Federal International Finance yang sudah dimulai sejak tahun 2010 lalu ke arah yang lebih baik dari segala elemen perusahaan. Salah satu strategi transformasi bisnis tersebut adalah rebranding yakni perubahan citra FIF baik dari luar maupun dalam untuk mendukung bisnis FIF yang semakin berkembang. Setiap perubahan merk bertujuan untuk memberikan 
kepuasaan kepada yang lebih mendalam. Seperti yang dikatakan Tjiptono (2008) bahwa "kepuasan dapat diartikan sebagai upaya pemenuhan sesuatu atau membuat sesuatu memadai dan ketidak puasan pelanggan adalah respon pelanggan terhadap evaluasi ketidak sesuaian (disconfirmation) yang dirasakan antara harapan sebelumnya (norma kinerja lain) dan kinerja actual produk yang dirasakan setelah pemakaianya". Giese dan Cote dalam Tjiptono (2008) menyatakan bahwa kepuasan pelanggan mencakup tiga komponen utama, yaitu: 1) kepuasan pelanggan merupakan respon emosional dan kognitif, 2) respons tersebut menyangkut fokus tertentu (ekspektasi, produk, pengalaman, konsumsi dan seterusnya), 3) respons terjadi pada waktu tertentu (setelah konsumsi, setelah pemilihan produk/jasa, berdasarkan pengalaman akumulasi).

Selama menjalankan bisisnya PT FIF umumnya terus mengalami peningkatan penjualan serta laba perusahaan. Peningkatan laba bersih perusahaan juga terjadi setelah menggunakan nama FIFGROUP, sehingga tidak diketahui dengan pasti apakah perubahaan brand PT. FIF menjadi FIFGROUP yang baru berlangsung sekitar delapan bulan terakhir ini mendapat tanggapan positif dari pelanggan. Apakah konsumen maupun calon konsumen memberikan tanggapan terhadap perubahan tersebut?.

Peningkatan hasil penjualan tidaklah berarti bahwa FIFGROUP terbebas dari berbagai masalah baik masalah yang datang dari luar maupun masalah internal perusahaan. Perusahaan multifinance harus mampu mempertahankan reputasinya dalam hal faktor pendanaan, marketing, GCG, corporate communication, CSR, IT, manajemen risiko, dan kinerja direksinya.

Berdasarkan pada paparan tersebut, tujuan penelitian ini adalah 1) untuk mengetahui tingkat respon dan kesadaran konsumen terhadap perubahan merek dagang yang digunakan perusahaan, 2) untuk mengetahui tingkat kepuasan konsumen terhadap perubahan merek pada perusahaan sehingga siketahui dampak dari perubahan merek tersebut terhadap tingkat loyalitas pelanggan. Jadi permasalahan yang dikaji dalam penelitian ini adalah;

1. Apakah terdapat pengaruh perubahan merek terhadap loyalitas pelanggan?

2. Apakah terdapat pengaruh perubahan merek terhadap kepuasan konsumen?

3. Apakah terdapat pengaruh perubahan merek terhadap terdapat loyalitas pelanggan melalui kepuasan konsumen?

\section{METODOLOGI PENELITIAN}

\subsection{Metode Penelitian}

Penelitian ini menggunakan pendekatan kuantitatif, yaitu penelitian yang menitikberatkan pada pengujian hipotesis, dengan menggunakan data terukur untuk mengambil suatu kesimpulan dari pengaruh antara perubahan merek dan kepuasan konsumen terhadap loyalitas pelanggan.

\subsection{Populasi}

Populasi dalam penelitian ini adalah seluruh pelanggan FIF Group yang tersebar diseluruh wilayah Indonesia. Saat ini jumlah pelanggan existing FIF Group mencapai 8 (delapan) juta dimana sekitar 4 (empat) juta adalah pelanggan aktif, yakni pelanggan yang kreditnya masih berjalan. Sisanya pelanggan yang sudah lunas.

\subsection{Sampel}

Teknik pengambilan sampel penelitian ini menggunakan teknik purposive sampling yaitu teknik sampling yang digunakan oleh peneliti jika memiliki pertimbangan-pertimbangan tertentu dalam pengambilan sampelnya (Idrus, 2002). Penelitian ini menentukan sampel penelitian sesuai dengan kebutuhan penelitian. Dalam hal ini sampel yang dipilih adalah pelanggan yang telah melakukan pembelian minimal dua kali di FIFGROUP. Dimana sampel diambil pada sepuluh wilayah yaitu wilayah DKI Jakarta, DIY Yogjakarta, Jawa Tengah, Surabaya, Bandung, Medan, Bandar Lampung, Palembang, Balikpapan, dan Samarinda, dan masing-masing wilayah diambil sampel sebanyak 15 orang sehingga jumlah sampel yang digunakan dalam penelitian ini adalah 150 responden.

\subsection{Instrumen Penelitian}

Instrumen dalam penelitian ini adalah kuesioner untuk variable perubahan merek, kepuasan konsumen, dan loyalitas pelanggan. Pertanyaan dalam kuesioner untuk masing-masing indikator yang disebarkan kepada responden disusun dengan menggunakan skala Likert. Jawaban atas pertanyaan kuesioner menggunakan skala sebagai berikut:

$\begin{array}{ll}\text { SS (5) } & \text { : Sangat Setuju } \\ \text { S (4) } & \text { : Setuju } \\ \text { TT (3) } & \text { : Tidak Tahu/Ragu-ragu } \\ \text { TS (2) } & \text { : Tidak Setuju } \\ \text { STS (1) } & \text { : Sangat Tidak Setuju }\end{array}$

\subsection{Teknik Analisis Data}

1. Analisis Regresi Linier Berganda

Analisis regresi berganda dalam penelitian ini digunakan untuk mengetahui pengaruh perubahan merek dan kepuasan konsumen terhadap loyalitas pelanggan. Adapun bentuk model yang akan diuji dalam penelitian ini adalah (Hair, Black, J.Babin, Anderson, \& L.Tatham., 2006):

$\mathrm{Y}=\mathrm{a}+\mathrm{b} 1 \mathrm{X} 1+\mathrm{b} 2 \mathrm{X} 2+\mathrm{b} 3 \mathrm{X} 3+\mathrm{e}$

Keterangan:

$\begin{array}{ll}\mathrm{Y} & \text { : Loyalitas Pelanggan } \\ \mathrm{X} 1 & \text { : Perubahan Merek } \\ \mathrm{X} 2 & : \text { Kepuasan Konsumen } \\ \mathrm{e} & \text { : Faktor error }\end{array}$


a : Konstanta

b1,b2,b3: Koefisien Regresi

2. Uji Ketepatan Parameter Penduga ( $t$ test)

Uji t digunakan untuk menguji koefisien regresi secara parsial dari variabel independensinya. Untuk menentukan nilai t-statistik tabel digunakan tingkat signifikansi $5 \%$ derajat kebebasan (degree of fredoom $) \mathrm{df}=(\mathrm{n}-\mathrm{k})$ dimana $\mathrm{n}$ adalah jumlah sampel dan $\mathrm{k}$ adalah banyaknya koefisien regresi. Kriteria uji yang digunakan adalah (Priyatno, 2009). Jika nilai signifikansi $>0,05$, maka Ho ditolak. Jika nilai signifikansi $<0,05$, maka Ho diterima. Adapun hipotesisnya adalah;

a. Ho : b1; b2; b3 = 0 artinya tidak terdapat pengaruh parsial dari seluruh variabel bebas (X) terhadap variabel terikat $(\mathrm{Y})$.

b. Ha : b1; b2; b3 $\neq 0$ artinya terdapat pengaruh yang signifikan secara parsial dari seluruh variabel bebas $(\mathrm{X})$ terhadap variabel terikat $(\mathrm{Y})$.

\section{Uji Simultan (Uji F-statistik)}

Uji F-statistik digunakan untuk menguji besarnya pengaruh dari seluruh variabel independen secara bersama-sama (simultan) terhadap variabel dependen. Pembuktian dilakukan dengan cara membandingkan nilai F kritis (Ftabel) dengan nilai Fhitung yang terdapat pada tabel analysis of variance. Untuk menentukan nilai F-tabel, tingkat signifikansi yang digunakan sebesar 5\% dengan derajat kebebasan (degree of freedom) df2 $=(n-k)$ dan df1 = (k-1) dimana $\mathrm{n}$ adalah jumlah sampel dan $\mathrm{k}$ adalah banyaknya koefisien regresi. Adapun kriteria uji yang digunakan adalah;

Jika nilai signifikansi $>0,05$ maka Ho ditolak

Jika nilai signifikansi < 0,05, maka Ho diterima

Adapun hipotesisnya adalah :

a. Ho:b1;b2;b3=0 artinya tidak terdapat pengaruh positif secara bersama-sama dari seluruh variabel bebas $(\mathrm{X})$ terhadap variabel terikat (Y). Arti secara statistik data yang digunakan membuktikan bahwa variabel bebas (X) berpengaruh terhadap variabel terikat $(\mathrm{Y})$.

b. Ha : b1; b2; b3 $\neq 0$ artinya terdapat pengaruh secara bersama-sama dari seluruh variabel bebas (X) terhadap variabel terikat (Y). Arti secara statistik data yang digunakan membuktikan bahwa variabel bebas (X) berpengaruh terhadap variabel terikat (Y).

\section{HASIL PENELITIAN DAN PEMBAHASAN 3.1 Deskripsi Data Temuan}

Analisis regresi linear berganda dilakukan untuk mengeta hui ada tidaknya pengaruh antara perubahan merek dan kepuasan konsumen terhadap loyalitas pelanggan, baik pengaruh secara sendirisendiri maupun pengaruh secara bersama-sama. Berdasarkan hasil perhitungan regresi berganda menggunakan program SPSS 17 didapatkan hasil berikut:
Tabel 1. Hasil Perhitungan Regresi Berganda

\begin{tabular}{|c|c|c|c|c|c|c|c|}
\hline \multirow[b]{2}{*}{ Model } & $\begin{array}{l}\text { Unstanc } \\
\text { d Coeff }\end{array}$ & $\begin{array}{l}\text { lardize } \\
\text { icients }\end{array}$ & $\begin{array}{l}\text { Standa } \\
\text { rdized } \\
\text { Coeffi } \\
\text { cients } \\
\end{array}$ & \multicolumn{4}{|c|}{$\begin{array}{l}\text { Collinearity } \\
\text { Statistics }\end{array}$} \\
\hline & B & $\begin{array}{l}\text { Std. } \\
\text { Error }\end{array}$ & Beta & $\mathrm{t}$ & Sig. & $\begin{array}{c}\text { Tolera } \\
\text { nce }\end{array}$ & VIF \\
\hline 1 (Constant) & 11.216 & 1.254 & & 8.942 & .000 & & \\
\hline $\begin{array}{l}\text { PERUBAH } \\
\text { AN } \\
\text { MEREK }\end{array}$ & .089 & .045 & .217 & 1.957 & .052 & .533 & 1.876 \\
\hline $\begin{array}{l}\text { KEPUASA } \\
\mathrm{N} \\
\text { KONSUM } \\
\text { EN }\end{array}$ & -.141 & .059 & -.263 & -2.372 & .019 & .533 & 1.876 \\
\hline
\end{tabular}

Sumber :(data olahan tahun 2014)

Berdasarkan tabel hasil perhitungan regresi linear berganda di atas, maka persamaan regresi linear berganda dapat ditulis sebagai berikut:

$$
\mathrm{Y}=11,216+0,089 \mathrm{X} 1-0,141 \mathrm{X} 2
$$

Dari hasil olahan data tersebut dapat dipahami bahwa;

1. Nilai konstanta adalah 11,216 artinya jika perubahan merek dan kepuasan konsumen bernilai 0 maka loyalitas pelanggan bernilai 11,216 .

2. Nilai koefisien kepuasan konsumen bernilai yaitu 0,089 artinya setiap terjadi peningkatan perubahan merek sebesar 1 (satu) satuan akan mengakibatkan kepuasan konsumen meningkat sebesar 0,089 dengan asumsi variabel lain tetap.

3. Nilai koefisien loyalitas pelanggan adalah 0,141 artinya setiap terjadi peningkatan perubahan merek sebesar 1 (satu) maka akan mengakibatkan loyalitas pelanggan menurun sebesar 0,141 dengan asumsi variabel lain tetap

Tabel 2. Hasil Perhitungan Koefisien Korelasi

\begin{tabular}{lllllll}
\hline IModel & $\mathrm{R}$ & : Square & $\begin{array}{c}\text { djusted R } \\
\text { Square }\end{array}$ & $\begin{array}{c}\text { Error of the } \\
\text { Estimate }\end{array}$ & $\begin{array}{l}\text { Durbin- } \\
\text { Watson }\end{array}$ \\
\hline & $.195^{\mathrm{a}}$ & .038 & .025 & 2.687313 & 1.880
\end{tabular}

Sumber :(data olahan tahun 2014)

Dari tabel 2 diketahui bahwa nilai $\mathrm{R}$ adalah 0,195 hal ini menunjukkan terjadi hubungan yang sangat lemah antara variabel indepenen yaitu perubahan merek dan kepuasan konsumen tehadap variabel dependen (loyalitas pelanggan) karena nilai $\mathrm{R}$ mendekati 0 . Setalah dianalisis dan diamati diketahui bahwa ada tingkat keraguan masyarakat dengan merk baru. Mereka belum mengetahui bahwa perubahan merk tersebut tidak merubah esensi kualitas perusahaan dalam menyediakan jasa atau barang. Artinya bahwa dalam proses perubahan merk, sebaiknya perusahaan merancang logo, kalimat yang jelas

Nilai R2 adalah 0,038 artinya kontribusi variabel perubahan merek dan kepuasan konsumen terhadap loyalitas pelanggan sebesar $3,8 \%$ sedangkan sisanya 
dipengaruhi oleh variabel lain yang tidak dimasukkan dalam model ini.

\subsection{Pengujian Hipotesis}

1. Uji t untuk variabel perubahan merek Ho = Perubahan merek tidak berpengaruh terhadap loyalitas pelanggan

$\mathrm{Ha}=$ Perubahan merek berpengaruh terhadap loyalitas pelanggan

Kriteria penerimaan atau penolakan hipotesis adalah:

a. Jika $\mathrm{t}$ hitung $<\mathrm{t}$ tabel, maka Ho diterima dan Ha ditolak

b. Jika t hitung > t tabel, maka Ho ditolak dan Ha diterima

Hasil Uji signifikan dengan kriteria:

a. Jika Sig. $\geq 0,05$ maka Ho diterima, artinya tidak Signifikan

b. Jika Sig. $\leq 0,05$ Maka Ha diterima, artinya Signifikan

Berdasarkan tabel 2, nilai t hitung 1,957 dan signifikan 0,052. Sedangkan $\mathrm{t}$ tabel pada tingkat signifikansi 0,05 dan derajat bebas (df) adalah df = $\mathrm{n}-\mathrm{k}-1=150-2-1=147$ didapatkan nilai sebesar 1.976. Dengan demikian nilai $\mathrm{t}$ hitung $<\mathrm{t}$ tabel $(1,957<1.976)$. Begitu pula dengan nilai signifikansi >0,05 $(0,052>0,005)$. Maka Ho diterima dan $\mathrm{Ha}$ ditolak. Sehingga dapat disimpulkan bahwa perubahan merek tidak berpengaruh terhadap loyalitas pelanggan.

\section{Uji t untuk variabel kepuasan konsumen}

$\mathrm{Ho}=$ Kepuasan konsumen tidak berpengaruh terhadap loyalitas pelanggan

$\mathrm{Ha}=$ Kepuasan konsumen berpengaruh terhadap loyalitas pelanggan

Dengan kriteria yang sama seperti di atas, maka berdasarkan tabel di atas nilai t-hitung -2.372 dan signifikan 0,019. Sedangkan t-tabel pada tingkat signifikansi 0,05 dan derajat bebas $\mathrm{df}=\mathrm{n}-\mathrm{k}-1=150$ $-2-1=147$ didapatkan nilai sebesar 1,976 . Dengan demikian nilai $\mathrm{t}$ hitung $<\mathrm{t}$ tabel $(-2.372<$ $1,976)$. Begitu pula dengan nilai signifikansi $>0,05$ $(0,019>0,005)$. Maka Ho diterima dan $\mathrm{Ha}$ ditolak.Sehingga dapat disimpulkan bahwa kepuasan konsumen tidak berpengaruh terhadap loyalitas pelanggan.

\section{Uji F}

Untuk mengetahui perubahan merek dan kepuasan konsumen secara bersama-sama berpengaruh atau tidak terhadap loyalitas pelanggan digunakan uji F. Adapun hipotesis uji adalah:

Ho $=$ Perubahan merek dan kepuasan konsumen secara bersama-sama tidak berpengaruh terhadap loyalitas pelanggan

$\mathrm{Ha}=$ Perubahan merek dan kepuasan konsumen secara bersama-sama berpengaruh terhadap loyalitas pelanggan

Kriteria pengujian:
Jika $\mathrm{F}$ hitung $\leq \mathrm{F}$ tabel, Ho diterima

Jika F hitung $\geq \mathrm{F}$ tabel, Ho ditolak

Untuk mengetahui $\mathrm{F}$ tabel pada tingkat signifikansi 0,05 adalah

df $1=$ jumlah variabel $-1=3-1=2$,

df $2=\mathrm{n}-\mathrm{k}-1=150-2-1=147 \mathrm{di}$

dapatkan nilai $\mathrm{F}$ tabel 3.06

Untuk mengetahui nilai $F$ hitung dapat digunakan tabel hasil perhitungan mnggunakan SPSS sebagai berikut:

Tabel 3. Hasil Uji F

\begin{tabular}{|c|c|c|c|c|c|}
\hline Model & $\begin{array}{l}\text { Sum of } \\
\text { Squares }\end{array}$ & df & $\begin{array}{c}\text { M } \\
\text { Square }\end{array}$ & $\mathrm{F}$ & Sig. \\
\hline Regression & 42.164 & 2 & 21.082 & 2.919 & $.057^{a}$ \\
\hline Residual & 1061.583 & 147 & 7.222 & & \\
\hline Total & 1103.746 & 149 & & & \\
\hline
\end{tabular}

Sumber :(data olahan tahun 2014)

Berdasarkan tabel di atas, nilai $\mathrm{F}$ hitung $\mathrm{F}$ table $(2,919<3,06)$ maka Ho diterima artinya perubahan merek dan kepuasan konsumen secara bersama-sama tidak berpengaruh terhadap loyalitas pelanggan.

\subsection{Pembahasan}

\section{Perubahan Merek FIFGROUP}

Perubahan nama dan logo baru ini merupakan wujud strategi transformasi bisnis PT Federal International Finance yang sudah dimulai sejak tahun 2010 lalu ke arah yang lebih baik dari segala elemen perusahaan. Salah satu strategi transformasi bisnis tersebut adalah rebranding yaitu perubahan nama menjadi FIFGROUP. Perubahan ini merupakan bentuk perbaikkan citra FIF baik dari luar maupun dalam untuk mendukung bisnis FIF yang semakin berkembang.

Perubahan merek (rebranding) FIFGROUP merupakan upaya untuk mengubah total serta memperbaharui citra merek yang telah ada agar menjadi lebih baik, dengan tidak mengabaikan tujuan awal dari perusahaan tersebut. Perubahan merek dan logo ini telah mengeluarkan biaya yang cukup besar. Selain itu perusahaan telah mengkaji berbagai hal sehubungan dengan perubahan merek perusahaan serta perubahan nilai-nilai yang terkandung dalam merek itu sendiri.

\section{Tanggapan Konsumen terhadap Perubahan} Merek

a. Respon Konsumen terhadap Perubahan Merek

Indikator yang digunakan untuk mengukur respon konsumen terhadap perubahan merek adalah: (1). Attention, (2). Interest, (3). Search, (4). Action, (5). Share. Berdasarkan analisis mengenai respon konsumen terhadap perubahan merek dan logo perusahaan melalui indikator-indikator di atas didapatkan bahwa secara umum pelanggan setuju 
bahwa indikator-indikator tersebut dapat memberikan penjelasan mengenai respon pelanggan terhadap perubahan merek dan logo FIFGROUP. Dalam hal ini pelanggan memberikan perhatian terhadap perubahan merek, pelanggan tertarik terhadap perubahan tersebut, pelanggan juga mencari informasi mengenai perubahan merek perusahaan dan pelanggan juga melakukan tindakan atas perubahan merek tersebut serta menyampaikannya kepada orang lain.

b. Persepsi Konsumen terhadap Ekuitas Merek Indikator yang digunakan untuk mengukur persepsi konsumen terhadap ekuitas merek adalah: (1) Brand awareness, (2). Perceived quality, (3).Brand loyalty, (4).Brand association

Berdasarkan indikator-indikator dari persepsi konsumen terhadap ekuitas merek FIFGROUP didapatkan bahwa secara umum pelanggan setuju bahwa indikator-indikator tersebut dapat menjelaskan persepsi pelanggan terhadap ekuitas merek FIFGROUP. Dalam hal ini responden mengetahui perubahan merek, memberikan penilaian terhadap keseluruhan kualitas produk, merasa loyal serta berkesan terhadap perusahaan

\section{c. Persepsi Konsumen terhadap Perubahan Merek}

Indikator yang digunakan untuk mengukur persepsi konsumen terhadap perubahan merek adalah: (1), Simbol, (2) Nama merek, (3)Warna, (4)Tulisan.

Berdasarkan indikator-indikator di atas dapat dinyatakan bahwa pelanggan umumnya setuju bahwa persepsi pelanggan terhadap perubahan merek dan logo perusahaan dapat dijelaskan oleh indikator-indikator tersebut. Dalam hal ini pelanggan mengenali simbol FIFGROUP, mengetahui nama merek perusahaan yang baru, menghayati warna serta tulisan yang ada dalam logo perusahaan dengan harapan FIFGROUP lebih memperhatikan hubungan baik dengan pelanggan.

\section{Kepuasan Konsumen}

Untuk mengetahui jawaban responden, tiap-tiap indikator dibuatkan sebuah buah pertanyaan yang disebarkan kepada 150 responden sebagai berikut:

1. Persepsi terhadap produk. Indikator yang digunakan untuk mengukur persepsi konsumen terhadap perubahan merek adalah (1) Persepsi terhadap kualitas produk, (2) Persepsi terhadap harga, (3) Mudah didapat.

2. Kinerja Produk. Indikator yang digunakan untuk mengukur persepsi konsumen terhadap perubahan merek adalah: (1) Kecepatan dalam pelayanan, (2). Ramah dalam pelayanan

3. Harapan dari produk. Indikator yang digunakan untuk mengukur persepsi konsumen terhadap perubahan merek adalah (1) Sesuai kebutuhan, (2) Harapan terhadap kualitas layanan, (3) Harapan terhadap keamanan produk.
Berdasarkan indikator-indikator di atas baik dalam dimensi persepsi terhadap produk, kinerja produk maupun harapan dari produk didapatkan bahwa umu mnya responden setuju terhadap indikator-indikator tersebut sehingga dapat memberikan penjelasan mengenai kepuasan konsumen terhadap perubahan merek dan logo FIFGOUP. Dalam hal ini responden merasakan kepuasan terhadap FIFGROUP setelah memberikan persepsi terhadap kualitas produk, persepsi terhadap harga dan kemudahan produk tersebut didapat. Selain itu responden juga memberikan nilai kepuasan berdasarkan persepsinya terhadap kinerja produk yaitu kecepatan serta ramah dalam pelayanan, Responden juga memberikan penilaian terhadap kepuasan berdasarkan harapan dari produk yang dibelinya melalui harapan sesuai kebutuhan, kualitas pelayanan dan rasa keamanan menggunakan produk FIFGROUP.

\section{Loyalitas Pelanggan}

Untuk mengetahui jawaban responden, tiap-tiap indikator dibuatkan sebuah buah pertanyaan yang disebarkan kepada 150 responden sebagai berikut:

1. Komitmen. Indikator yang digunakan untuk mengukur komitmen terhadap perubahan merek adalah: (1). Tidak membandingkan dengan produk pesaing, (2). Mereferensikan kepada orang lain

2. Konsistensi. Indikator yang digunakan untuk mengukur komitmen terhadap perubahan merek adalah: (1). Mengajukan kredit ulang, (2) membayar cicilan tepat waktu.

Berdasarkan indikator-indikator di atas baik dalam dimensi kominten maupun konsistensi dapat dinyatakan bahwa secara umum responden setuju atas indikator-indikator tersebut sehingga dapat memberikan penjelasan yaitu responden memiliki tingkat loyalitas tertentu terhadap FIFGROUP karena memiliki sikap komitmen untuk tidak membandingkan dengan produk pesaing serta mereferensikan kepada orang lain. Responden juga memiliki sikap konsistensi mengajukan kredit ualng serta melakukan pembayaran cicilan tepat waktu.

Temuan tersebut sesuai dengan konsep dari Hasan (2008) bahwa loyalitas pelanggan adalah sebagai orang yang membeli, khususnya yang membeli secara teratur dan berulang-ulang. Pelanggan merupakan seseorang yang terus menerus dan berulang kali datang ke suatu tempat yang sama untuk memuaskan keinginannya dengan memiliki suatu produk atau mendapatkan suatu jasa dan membayar produk atau jasa tersebut. Loyalitas pelanggan merupakan salah satu tujuan inti yang diupayakan dalam pemasaran modern. Hal ini dikarenakan dengan loyalitas diharapkan perusahaan akan mendapatkan keuntungan jangka panjang atas hubungan mutualisme yang terjalin dalam kurun waktu tertentu. 


\section{Keterbatasan Penelitian}

Dalam melakukan penelitian ini, peneliti dihadapi beberapa kendala sehingga menjadi keterbatasan yang sulit untuk dihindari. Adapun keterbatasan tersebut antara lain:

\section{Kendala rahasia perusahaan}

Beberapa pertanyaan yang diajukan saat wawancara kepada pihak perusahaan tidak mendapatkan jawaban secara luas sesuai harapan penulis seperti pertanyaan mengenai jumlah biaya yang dikeluarkan perusahaan untuk melakukan perubahan merek, perubahan-perubahan internal yang terjadi sehubungan dengan adanya perubahan merek dan logo perusahaan serta berbagai kajian lainnya yang dilakukan perusahaan sehubungan dengan perubahan yang dilakukan, sehingga penulis tidak dapat memberikan gambaran secara lebih rinci mengenai perubahan merek dan logo perusahaan.

2. Kendala dalam mengumpulkan data

Mengingat FIFGROUP memiliki kantor cabang yang tersebar secara luas di wilayah Indonesia dengan jumlah pelanngan mencapai hingga 4 juta pelnggan dari seluruh wilayah tersebut. Maka pengumpulan data yang dilakukan penulis hanya membagi wilayah berdasarkan kantor-kantor cabang yang berada di kota-kota besar saja hal ini dilakukan karena penulis mendapatkan kesulitan untuk mengetahui dengan pasti mengenai jumlah pelanggan di masing-masing kantor cabang perusahaan.

\section{KESIMPULAN}

\section{Kesimpulan}

Berdasarkan pembahasan yang dilakukan di atas, dapat ditarik beberapa kesimpulan sebagai berikut:

1. Perubahan merek dan logo PT. FIF menjadi FIFGROUP dilandasi oleh berbagai pertimbangan persaingan bisnis yaitu perubahan lingkungan bisnis yang terjadi seperti kebijakan pemerintah dalam kenaikkan BI rate, rencana kenaikan harga bahan bakar minyak (BBM), pelemahan rupiah, melonjaknya inflasi. Perusahaan juga mempertimbangkan kondisi resiko kredit macet yang sering dialami, krisis image pelanggan terhadap perusahaan, serta keinginan untuk melakukan perubahan visi perusahaan.

2. Berdasarkan tanggapan pelanggan yang pernah melakukan pembelian ulang produk FIFGROUP diberbagai wilayah yang tersebar diseluruh Indonesia diketahui bahwa umumnya pelanggan mengetahui serta memberikan respon yang baik atas perubahan merek dan logo PT. FIF menjadi FIFGROUP, Namun demikian pelanggan tidak memahami makna serta nilai yang terkandung dari perubahan merek dan logo tersebut. Hal ini disebabkan karena pihak perusahaan belum menggunakan

2. prospektif. Dan perusahan harus melakukan sosisalisasi seintensif mungkin. strategi yang tepat dalam menyebarkan perubahan merk tersebut, sehingga tingkat keyakinan masyarakat berkurang.

3. Berdasarkan tanggapan pelanggan mengenai kepuasan konsumen didapatkan bahwa secara umum pelanggan menyetujui bahwa perubahan merek dan logo PT FIF menjadi FIFGROUP memberikan harapan terhadap kepuasan konsumen selama menggunakan produk FIFGROUP.

4. Berdasarkan hasil perhitungan menggunakan regresi berganda didapatkan bahwa terjadi hubungan yang sangat lemah antara variabel indepenen yaitu perubahan merek dan kepuasan konsumen terhadap variabel dependen (loyalitas pelanggan) dimana kontribusi variabel perubahan merek dan kepuasan konsumen terhadap loyalitas pelanggan hanya sebesar $3,4 \%$. Perolehan persentase tersebut tetap memberikan pemahaman bahwa ada pengaruh perubahan merk terhadap tingkat kepuasaan pelanggan walaupun rendah. Namun tingkat persentase tersebut dipengaruhi oleh keberadaan design logo, gradasi warna simbol, pemilihan diksi, dan tingkat kejelasan penyebaran informasi kepada khalayak ramai.

5. Berdasarkan hasil uji hipotesis ditemukan bahwa baik secara sendiri-sendiri maupun secara bersama-sama perubahan merek dan kepuasan konsumen tidak berpengaruh terhadap loyalitas pelanggan. Bahkan tanda koefisien X2 bernilai negatif yang berlawanan dengan teori. Hal ini disebabkan karena perubahan merk menimbulkan asumsi atau paradigma baru dari masyarakat atau konsumen. Sehingga hal ini berdampak pada perubahan kepuasaan pelanggang, akhirnya loyalitas pelanggang menjadi berkurang. Namun, jika masyarakat telah memiliki keyakinan terhadap perubahan merk tersebut bisa memberikan perubahan terhadap kepuasaan pelanggang dan loyalitas pelanggang.

\section{Saran}

Berdasarkan kesimpulan di atas, ditemukan sebagai berikut:

1. Dari hasil penelitin diperoleh hubungan yang tidak signifikan antara perubahan merek, kepuasan konsumen terhadap loyalitas pelanggan. Baik secara sendiri-sendiri maupun secara simultan. Dan kepuasan konsumen berpengaruh negatif terhadap loyalitas pelanggan. Hal ini mungkin disebabkan karena kebijakan perubahan merek dari PT. FIF menjadi FIFGROUP baru berlangsung dalam satu tahun. Sehingga masih perlu sosialisasi kepada pelanggan maupun calon pelanggan yang

3. Dimasa mendatang perlu dilakukan penelitian untuk menjelaskan loyalitas pelanggan dengan 
menggunakan variabel-variabel lain selain perubahan merek dan kepuasan konsumen dan kepuasan pelanggan. Disarankan variabel seperti kualitas pelayanan, promosi dan manajemen komunikasi terhadap pelanggan disertakan di dalam model analisis regresi.

4. Untuk penelitian berikutnya disarankan agar dilakukan komunikasi dan penjelasan yang rinci mengenai butir-butir pertanyaan yang ditanyakan kepada responden, supaya mereka memahami ketika diminta mengisis kuisioner.

\section{DAFTAR PUSTAKA}

Hair, J. F. J., Black, W. C., J.Babin, B., Anderson, R. E., \& L.Tatham., R. (2006). Multivariate Data Analysis 6th. New Jersey: Pearson Prentice Hall Education International.

Hasan, A. (2008). Marketing. Yogyakarta: Media Utama.

Idrus, M. (2002). Metode Penelitian Ilmu Sosial. Pendekatan Kualitatif dan Kuantitatif. Edisis kedua. Jakarta: Erlangga.

Juntunen, M., Saraniemi, S., \& Jussila, R. (2009). Corporate re-branding as a process. In Proceedings of the 5th Thought Leaders International Conference on Brand
Management. Athens.

Keller, K., Aperia, T., \& Georgson, M. (2008). Strategic Brand Management: A European Perspective. Prentice Hall College Div.

Kertajaya, H. (2004). Positioning. Bandung: Mizan.

Kotler, P., \& Keller, K. L. (2007). Manajemen Pemasaran Edisi 12 Jilid 1. Jakarta: IndeksPrentice Hall.

Muzellec, L., \& Lambkin, M. (2006). Corporate rebranding: destroying, transferring or creating brand Equity.

Priyatno, D. (2009). 5 Jam Belajar Olah Data engan SPSS 17. Yogyakarta: Andi.

Ratri, L. E. (2007). Hubungan Antara Citra Merek (Brand Image) Operator Seluler dengan Loyalitas Merek (Brand Loyalty) Pada Mahasiswa Pengguna Telepon Seluler di Fakultas Ekonomi Reguler Universitas Diponegoro Semarang. Universitas Diponegoro.

Schultz, D., \& Schultz, H. F. (2004). Brand Babble: Sense and nonsense about branding. Ohio: Thomson South-western.

Tjiptono, F. (2008). Pemasaran Jasa. Malang: Bayumedia. 